\title{
THE PHRASE STRUCTURE OF PHASE VERBS: AN INITIAL CONTRASTIVE ANALYSIS OF ENGLISH AND RUSSIAN*
}

\author{
JONATHAN E. MACDONALD \\ Department of Linguistics \\ Department of Spanish, Italian \& Portuguese \\ University of Illinois \\ 707 South Mathews Avenue \\ Urbana, IL 61801 \\ USA \\ jonmacd@illinois.edu
}

\begin{abstract}
This squib carries out an initial contrastive analysis of English and Russian phase (a.k.a. aspectual) verbs. Following Fukuda's (2008; 2009) syntactic account of English, I assume English phase verbs can head one of two aspectual functional projections: H-AspP, located immediately above vP; or L-AspP, located between $v P$ and VP. Applying the same diagnostics to Russian, it appears that Russian phase verbs head only L-AspP. The relation between L-AspP and another structurally similar aspectual projection, AspP, proposed by MacDonald (2008a;b), is discussed. We see that L-AspP has a subset of the aspectual properties of AspP. Finally, I note how this approach to Russian phase verbs leads to the expectation that semantic properties of Russian phase verb complements play a role in some of the phase verb complement (in)compatibility patterns. In concrete, I suggest that the aspectual class of the complement plays a role.
\end{abstract}

Keywords: phase verbs, English, Russian, verb phrase structure, event structure, aspectual class

\section{Introduction}

This squib takes a comparative approach to the syntax of phase (a.k.a. aspectual) verbs, such as begin, continue, finish, etc. focusing on English and

* I would like to thank Balázs Surányi for his tremendous patience while I completed the present squib, as well as two anonymous reviewers for very useful comments that have led to a more clearly focused squib. All errors of course are my own. Part of this project was funded under the Hungarian Scientific Research Fund NF-73537. 
Russian. I adopt the fundamentals of Fukuda's (2008; 2009; to appear) approach to phase verbs in English and Japanese, in which phase verbs in these languages head one of two aspectual functional projections: $\mathrm{H}(\mathrm{igh})-$ AspP and L(ow)-AspP. Departing slightly from his approach, I assume that H-AspP is associated with viewpoint aspect (à la Smith 1991), while L-AspP is associated with situation aspect (à la Smith 1991). (See also Travis 1991 for structurally analogous aspectual projections.) In concrete, I assume that the semantic component reads event structure information off of the syntax. The semantics "looks at" H-AspP to ascertain information about the event as a whole, while it "looks at" L-AspP to ascertain information about properties internal to the event (i.e., initial and final bounds, and duration, the properties related to distinguishing aspectual predicate classes). In order to contribute to either type of event structure interpretation, an element must establish a relation with these relevant aspectual projections. In the case of phase verbs, that relation is one of heading an aspectual projection. We will see that, while there is evidence that in English both H-AspP and L-AspP can be occupied by phase verbs, it appears that in Russian, phase verbs only head L-AspP. A consequence for this approach is that we might expect that some phase verb complementation patterns can be explained by appeal to the event internal properties (i.e., the aspectual class) of the phase verb complement itself. Evidence that this is the case is offered.

This squib is organized as follows. In section $\mathbf{2}$, I discuss the syntactic properties of English phase verbs, adopting the diagnostics and conclusions from Fukuda (2008; 2009). We see that phase verbs that take to-infinitival complements head $\mathrm{H}$-AspP, while phase verbs that take gerundive phase verb complements head L-AspP. In section 3, I discuss these diagnostics as they apply to Russian, pointing out that Schoorlemmer (1994) has already noted many of the relevant cases. The conclusion drawn here is that Russian phase verbs can only head L-AspP. In section 4, I discuss in more detail how H-AspP and L-AspP are interpreted with respect to event structure information. Based on the syntactic conclusions about phase verbs and the event internal properties tied to L-AspP, an explanation of why stative predicates cannot be L-AspP phase verb complements arises naturally. In section 5, I contrast properties of a structurally identical aspectual functional projection, AspP, proposed in MacDonald (2008a;b), with L-AspP. We see that MacDonald's AspP subsumes the properties associated with L-AspP. In particular, in addition to being the syntactic locus of event internal properties, AspP has a syn- 
tactic property that allows elements to contribute to those event internal properties "at a distance" from AspP. In section 6, we see that while there is evidence that Russian does not have the particular syntactic property of AspP that allows semantic contributions to the event internal properties "at a distance", it does have L-AspP. That is, Russian has an aspectual projection where elements can contribute to the event internal properties of the predicate. In section $\mathbf{7}$, I discuss one consequence of this conclusion about Russian: the event internal properties of a phase verb complement can affect its (in)compatibility as a phase verb complement. That is, the aspectual class of a phase verb complement is relevant for understanding some of the phase verb complementation patterns. Section $\mathbf{8}$ concludes by briefly recapping the main points of the squib.

\section{The syntax of English phase verbs}

Based on a range of novel and previous observations, Fukuda (2008; 2009) proposes that English phase verbs are the heads of one of two aspectual functional projections, one of which is located immediately above $v \mathrm{P}$, which he labels H-AspP, and one of which is located between $v \mathrm{P}$ and $\mathrm{VP}$, which he labels L-AspP. His account assumes that phase verb constructions are essentially mono-clausal in nature, since there is only one TP. Evidence for the mono-clausal nature comes from the inability of two conflicting temporal expressions to appear at the same time with phase verbs taking a verbal complement, as illustrated in (1).

(1) (a) *Yesterday, John began/continued to eat the pizza today.

(b) *Yesterday, John finished/began/continued eating the pizza today.

Observe that this contrasts with control verbs, like want, which do allow two conflicting temporal expressions at the same time, a fact that has been taken as evidence for a bi-clausal complement structure (see, for instance, Marušič-Žaucer 2006 and references therein).

(2) Yesterday, John wanted to eat the pizza today.

Perlmutter (1970) observes that phase verbs do not put any special thematic restrictions on their subjects; their subjects can be non-thematic, as illustrated in (3). 
(3) (a) It began/continued to rain.

(b) It finished/began/continued raining. ${ }^{1}$

Fukuda suggests that because phase verbs head functional projections, there are no theta-role restrictions.

Finally, Fukuda (2008; 2009) observes that, like raising verbs, quantifier (QP) subjects of phase verbs with a to-infinitival complement show a scopal ambiguity with the phase verb itself, illustrated in (4). ${ }^{2}$

(4) Many children from the 8th grade continued to bring lunch to school.

(i) There were many children from the 8 th grade such that they continued to bring lunch to school.

(ii) It continued to be the case that many children from the 8 th grade brought lunch to school.

(4i) is a specific interpretation of many children, and (4ii) is an existential interpretation of many children. Fukuda also observes that this ambiguity is lost when the phase verb complement is gerundive, illustrated in (5); only the specific reading is available.

(5) Many children from the 8th grade continued bringing lunch to school.

(i) There were many children from the 8th grade such that they continued bringing lunch to school.

To explain this contrast, Fukuda $(2008 ; 2009)$ claims that when an English phase verb heads H-AspP, its complement is a to-infinitive, and when an English phase verb heads L-AspP, its complement is a gerundive. This accounts for the patterns in (4) and (5). On the one hand, the ambiguity with to-infinitival complements arises because many children can be interpreted in its base position in Spec, $v \mathrm{P}$, or in its derived position in Spec,TP. In Spec, $v \mathrm{P}$, many children is below the phase verb in $\mathrm{H}-\mathrm{AspP}$ and receives an existential interpretation. In Spec,TP, many children is above the phase verb in $\mathrm{H}$-AspP and receives a specific interpretation. With gerundive complements, in contrast, many children will always be

${ }^{1}$ Fukuda $(2008,173)$ cites Ross $(1972)$ who observes that finish is not very good with weather verbs: *It finished being muggy. Fukuda quotes examples such as After it finished raining, we went down to... from the internet to show it can appear as a phase verb complement.

2 Fukuda's $(2008,173)$ example is Someone from NY started to win/started winning the lottery. 
above the phase verb in L-AspP, whether in Spec, $v \mathrm{P}$ or Spec, TP, and will always receive a specific interpretation.

\section{The syntax of Russian phase verbs}

Schoorlemmer (1994) makes several observations about Russian phase verbs, which I take to suggest that they should be treated in a syntactically parallel way to English phase verbs. First, observe that like English phase verbs, Russian phase verbs can have non-thematic subjects, illustrated in (6).

(6) Načinaet/prodolžaet temnet. ${ }^{3}$

start/continue-3sg get.dark $\mathrm{impf}_{\mathrm{im}}$

'It is beginning/continuing to get dark.'

Observe also that, like in the case of English phase verbs, two conflicting temporal expressions are incompatible with Russian phase verbs and verbal complements, illustrated by Schoorlemmer $(1994,407)$ in (7).

(7) *V 4 časa, deti načali čitat' v 5 časov

at 4 o'clock children started readimpf at 5 o'clock

'At 4 o'clock, the children started to read at 5 o'clock.'

Following the line of reasoning laid out above, based on Fukuda (2008; 2009), I take these facts to mean that Russian phase verbs head a functional projection in a mono-clausal structure. In this respect, Russian phase verbs pattern exactly with English phase verbs. The next question is whether Russian phase verbs can head either H-AspP or L-AspP. The following data from Schoorlemmer $(1994,406)$ suggests that they can head H-AspP (translation added by author).

(8) Mnogie deti prodolžali prixodit'.

many children continued come impf

'Many children continued to come/coming.'

(i) there were many children such that they continued coming

(ii) it continued to be the case that many children came.

3 This example is based on an example from Schoorlemmer (1994). The observation is hers. Note also, that the glosses for the examples from Schoorlemmer (1994) have been modified (and simplified) for unification of glossing from the various sources cited throughout this squib. 
There is both a specific and an existential interpretation of the QP subject in (8). This suggests that this phase verb patterns with English phase verbs that take a to-infinitival complement, i.e., like phase verbs in H-AspP. However, given that the phase verb complement in (8) is an unaccusative verb, the existential reading may be the result of the base position of the subject as a complement of the verb, entailing that the phase verb would not have to head H-AspP for the ambiguity to arise; it could be in L-AspP. Some support that this may be the case comes from English phase verbs taking an unaccusative gerundive complement. In contrast to the transitive gerundive complements from (5), the unaccusative gerundive complements in (9) show an ambiguity with a QP subject.

(9) Many children from the 8th grade continued coming to class.

(i) there were many children from the 8 th grade such that they continued coming to class

(ii) it continued being the case that many children from the 8 th grade came to class

Moreover, when Russian phase verbs take a transitive complement, the existential interpretation of the QP subject appears no longer to be available, illustrated in (10).

(10) (a) Mnogie deti končili/prodolžali est' pizzu.

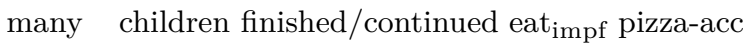
'Many children finished/continued eating pizza.'

(i) there were many children such that they finished/continued eating pizza

(b) Mnogie deti zakončili/perestali pronosit' obed $\mathrm{v}$ školu.

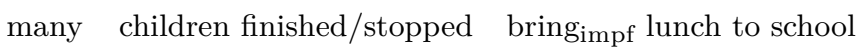
'Many children finished/stopped bringing lunch to school.'

(i) there were many children such that they finished/stopped bringing lunch to school

Following the logic of Fukuda's arguments, these facts suggest that Russian phase verbs head L-AspP only, contrasting with English. ${ }^{4}$

${ }^{4}$ This does not mean that Russian lacks H-AspP. It just means that Russian phase verbs can only head L-AspP. Note also that the fact that there is only one type of Russian phase verb (verbal) complement - in contrast to English which has to-infinitival and gerundive complements - is not necessarily related to the conclusions drawn above that Russian phase verbs head only a single as- 


\section{Interpreting H-AspP and L-AspP}

Fukuda (to appear) suggests that H-AspP and L-AspP are syntactic instantiations of event structure information. I assume that this is essentially correct, although I depart from Fukuda (to appear) in some minor details. I assume that the structural split between $\mathrm{H}-\mathrm{AspP}$ and L-AspP relates semantically to Smith's (1991) split between viewpoint and situation aspect, respectively. That is, phase verbs that appear in $\mathrm{H}$-AspP contribute semantically to the interpretation of the event as a whole, while phase verbs that head L-AspP contribute semantically to the interpretation of the properties internal to the event (such as initial and final event bounds and duration). I assume that semantics reads event structure information off of the structure, such that, for an element to contribute semantically to the event internal properties it must establish some syntactic relation with L-AspP, and for an element to contribute semantically to the event as a whole, it must establish some syntactic relation with H-AspP. ${ }^{5}$ Support for this split comes from the following series of observations.

Freed (1979) observes that stative predicates are infelicitous phase verb complements in general. When they do appear, they do so as to-infinitival complements. Observe the contrast between the gerundive complements in (11) and the to-infinitival complements in (12).

(11) (a) \# John started weighing 200 lbs. the last day of vacation.

(b) ${ }^{\#}$ That look continued meaning surprise.

(12) (a) John started to weigh 200 lbs. the last day of vacation.

(b) That look continued to mean surprise.

Consider the data in (13) in which there appear to be stative gerundive phase verb complements.

pectual functional projection, since Japanese also only has one type of phase verb (verbal) complement, yet, as argued by Fukuda (2007), there are phase verbs in Japanese that head H-Asp and L-Asp.

${ }^{5}$ The way in which phase verbs establish this relation is by heading the aspectual projection itself. Other syntactic means of establishing a relation with AspP may be by appearing in the specifier, or perhaps by Agreeing with one of the heads. I do not explore this range of options here, although I do suggest below that establishing a relation with AspP "at a distance" by being c-commanded by AspP is a point of variation among languages; some languages allow it, some do not. 
(13) (a) John began thinking about her again.

(b) John continued wondering about his future.

Although think and wonder are stative predicates, as gerundive complements, they take on eventive interpretations; they can be conceived of in terms of activities whereby mental processes are being carried out (see Katz 2008 for a discussion of stative-eventive shifts). These statives contrast with weigh and mean in (11) in that there seems to be no associated process that is conceivable with their lexical meaning given the context of the sentences. ${ }^{6}$ It is not unknown that statives can shift into eventive interpretations. Moreover, there are a variety of proposals that attempt to determine the conditions that determine these shifts (see, for instance, Dowty 1979; Mufwene 1984; Rothstein 2004; Smith 1983; 1991; de Swart 1998; Zucchi 1998). Due to space limitations, I will not attempt to pin down the precise conditions underlying the shift in (13). I simply note that this does appear to be what is happening.

Note that this alternation in event structure properties associated with gerundive complements is an indication that these gerundive complements interact with event internal properties of the predicate while to-infinitival complements do not, in as much as no shift to an eventive interpretation is necessarily required when statives are to-infinitival complements. In fact, Freed $(1979,153)$ observes a difference between these two classes of phase verb complements in English and states that to-infinitival complements allow "[...] reference not only to the particular temporal segments normally referred to by the [complement] verb in question, but also to the entire event named". Freed observes an interesting contrast in this respect, illustrated by examples parallel to hers in (14).

(14) (a) The barber started to trim his beard, but was interrupted before making the first snip.

(b) The barber started trimming his beard,

\# but was interrupted before making the first snip.

Since phase verbs taking to-infinitival complements refer to the event in its entirety, there is no entailment that the event described by the

${ }^{6}$ Note that there is another, more "activity" related lexical meaning of weigh in which one takes an object and places it on a scale, as in The pediatrician weighed the baby in the last visit. It can be a phase verb complement on this activity interpretation: The pediatrician stopped weighing the baby. 
complement predicate actually initiates in (14a); thus, the statement that the event did not actually begin is not contradictory and does not lead to infelicity. In contrast, with gerundive phase verb complements in (14b), reference is made directly to event internal properties, which, in this case, entails that the event described by the phase verb complement does actually begin; thus, the contradictory nature of the conjoined statement gives rise to infelicity.

I assume that these contrasts arise because H-AspP semantically contributes event structure information relevant to the interpretation of the event as a whole, while L-AspP semantically contributes event structure information relevant to the interpretation of properties internal to the event. I take this to explain why statives can appear as to-infinitival complements with no necessary shift to an eventive interpretation: the "whole state" can be referred to. Additionally, I assume that the shift to an eventive interpretation results from L-AspP necessarily contributing event internal properties that give rise to eventive interpretations, such that for a stative to be a gerundive complement to a phase verb, it can only be interpreted as eventive. I offer support for this assumption in the next section.

\section{How many aspectual projections in English?}

The discussion of the previous section ties L-AspP to event internal properties of a verb phrase. Independently, MacDonald (2008a;b) argues for the existence of an aspectual functional projection (AspP) in the same structural position as L-AspP that is directly related to the event structure properties of the predicate. In this section, I discuss MacDonald's (2008a;b) proposal and suggest that in English MacDonald's AspP and Fukuda's L-AspP function as a singular aspectual functional projection.

MacDonald (2008a,b) argues that there are two main functions of AspP: (1) it serves as the syntactic locus of event internal properties (i.e., initial and final temporal bounds, and duration). More concretely, elements must establish a relation with AspP in order to contribute to event internal properties; and (2) it allows elements to contribute to event internal properties "at a distance" from AspP, i.e., when c-commanded by AspP. Moreover, MacDonald (2008a;b) observes that eventive predicates contrast systematically with statives predicates in English with respect to three properties. He ties this contrast directly to the presence of AspP between $v \mathrm{P}$ and $\mathrm{VP}$ in eventive predicates and its absence in 
statives predicates. Consider the three properties that MacDonald bases this conclusion on.

The first is related to the aspectual influence of a noun (AIN) on the predicate, first observed by Verkuyl (1972), illustrated in (15).

(15) (a) John ate chicken ${ }^{*}$ in 10 minutes/for 10 minutes.

(b) John ate a chicken in 10 minutes/ $/{ }^{\#}$ for 10 minutes.

(15a) is atelic and (15b) is telic because of the mass noun and count noun respectively. Observe in (16) that statives do not show the AIN.

(16) (a) John owned stereo equipment/a T.V. for a month.

(b) John owed money/a buck for a month.

The second property that eventives show and statives lack is a particular multiple events interpretation of bare plurals (BPs), referred to as a sequence of similar events (SSE) interpretation, illustrated in (17a). Observe in (17b) that mass nouns do not elicit an SSE interpretation.

(17) (a) John ate chickens in 10 minutes for an hour straight.

(b) John ate chicken ${ }^{\#_{\text {in }}} 10$ minutes for an hour straight.

The SSE interpretation of (17a) is that John ate one chicken in 10 minutes, then another in 10 minutes, and so on for an hour straight. As indicated by the compatibility of the in-adverbial, the SSE interpretation is only available with telic predicates, already precluding this interpretation with statives, since they are atelic. Observe, nevertheless, the unavailability of the SSE interpretation with statives in (18).

(18) (a) John owned books ( ${ }^{*}$ in a week) for a month straight.

(b) John owed cars (\#in a week) for a month straight.

Finally, the third property that eventives show and statives lack is the ability of a prepositional phrase (PP) to induce telicity, illustrated in (19).

(19) (a) John carried a bag $\quad \#_{\text {in }} 10$ minutes/for 10 minutes.

(b) John carried a bag into the room in 10 minutes/\# for 10 minutes. $^{7}$

${ }^{7}$ Note that transitive activities are eventive predicates that do not show the properties discussed above which are claimed to be associated with eventive predicates. 
Observe that with statives, no PP can induce telicity, illustrated in (20).

(20) (a) John owed a car to the bank for a month/\# in a month.

(b) John was into the brownies last night for an hour/\# in an hour.

MacDonald (2008b) argues explicitly that these three properties are dependent on AspP. Since statives do not show these three properties, it is concluded that eventive predicates project AspP, while stative predicates lack AspP. Moreover, it is claimed that the event internal properties of a predicate (i.e., initial and final event bounds, and duration) are dependent on AspP, such that if AspP is absent in the verb phrase, the predicate lacks event internal properties; that is, the predicate is interpreted as stative. In this respect, a defining structural property of English stative predicates - which has corresponding semantic consequences - is the lack of AspP in their phrase structure.

Now, if we make the assumption that L-AspP and AspP - two aspectual projections occupying the same syntactic position - formed a single aspectual functional projection, (L-)AspP, then the fact that L-AspP phase verbs cannot take stative complements follows from the structural definition that statives lack AspP, since there are conflicting constraints on stative gerundive phase verb complements. That is, a gerundive phase verb complement requires (L-)AspP, but statives lack (L-)AspP. Arguably then, in English, L-AspP and AspP function as a single functional projection. What about in Russian?

\section{How many aspectual projections in Russian?}

If the absence of (i) the AIN; (ii) the SSE interpretation of BPs; and (iii) the ability of a PP to induce telicity is evidence for the lack of AspP, then we are forced to conclude that Russian lacks AspP, because as discussed in MacDonald (2008b; 2010) Russian lacks these three properties. First, note that, as Schoorlemmer (1995) already observed, Russian lacks the AIN, illustrated in (21).

As soon as a telicizing PP is added, as in (20b), they show all of these three properties. Note that this contrasts with statives. I assume that this is due to the lack of AspP with statives and the presence of AspP with eventive predicates, as argued above. 
(21) (a) Maria čitala knigu/poėziju *za čas/v tečenii časa. Mary $\operatorname{read}_{\text {impf book/poetry }} *_{\text {in hour/during hour }}$ 'Mary read a book/poetry in an hour/for an hour.'

(b) Maria pročitala knigu/poėziju za čas $/{ }^{*} \mathrm{v}$ tečenii časa. Mary pfread book/poetry in hour/*during hour 'Mary read a book/poetry in an hour/for an hour.'

The imperfective form is atelic and the perfective form is telic independently of the presence of a mass or count noun. ${ }^{8}$ Observe also that there is no SSE interpretation of a BP in Russian either, illustrated in (22); only a group interpretation is available.

(22) Maria pročitala knigi.

Mary pfread books

'Mary read books.'

Finally, observe that, as has been previously noted (see, for instance, Beck-Snyder 2001), Russian PPs do not turn atelic predicates into telic predicates, as illustrated in (23).

(23) Koška lezla na krišu doma * za čas/v tečenii časa.

cat climbedimpf onto roof house-gen $*$ in hour/during hour

'The cat climbed onto the roof of the house in an hour/for an hour.'

Recall from the discussion of English that the lack of these three properties was tied to the absence of (MacDonald's) AspP from the structure. Taken at face value then, we should conclude from this discussion that Russian lacks AspP. Additionally, it was observed that in English the lack of AspP was tied to a stative interpretation of the predicate. This would entail that, in Russian, all verbs should be statives, which is clearly not the case. Now recall from section $\mathbf{3}$ that we concluded that Russian has L-AspP. Moreover, we concluded in section $\mathbf{4}$ that L-AspP was tied to the event internal properties. What seems to be the case is that MacDonald's AspP subsumes Fukuda's L-AspP. That is, as argued by MacDonald (2008a;b), AspP has two functions: (1) it serves as the syntactic locus of event internal properties (i.e., initial and final temporal bounds, and duration). More concretely, elements must establish a relation with AspP in

8 There is a general factual interpretation of imperfectives under which a telic interpretation is available (see Borik 2002; Dickey 2000). Note also that it is not the case that all perfectives are telic. Nevertheless, the pattern noted in (21) does not change under a general factual interpretation or with atelic perfectives.

Acta Linguistica Hungarica 58, 2011 
order to contribute to event internal properties; and (2) it allows elements to contribute to event internal properties "at a distance" from AspP, i.e., when c-commanded by AspP. The first function seems to correspond to L-AspP. Thus, it appears that what Russian lacks are the properties that allow contributing to the event internal properties at a distance.

This seems to be correct. Recall one contrast between English and Russian: the ability of a PP to induce telicity. Prepositions induce telicity "at a distance" from the verb. In Russian, the only elements that can induce telicity are "very close" to the verb (i.e., prefixes). The English verb phrase has a wider space than the Russian verb phrase where elements can contribute to the aspectual interpretation of the predicate. What might be claimed then is that both English and Russian have L-AspP, but English L-AspP has an additional property - or perhaps set of features - such that elements within the verb phrase at a distance from it can contribute event internal properties.

\section{Aspectual class and Russian phase verb complementation}

It has been suggested that Russian phase verbs head an aspectual functional projection that appears between $v \mathrm{P}$ and $\mathrm{VP}$, L-AspP, but not an aspectual functional projection above $v \mathrm{P}, \mathrm{H}$-AspP. Moreover, it has been suggested that L-AspP contributes to the interpretation of event internal properties, while H-AspP contributes to the interpretation of the event as a whole. That is, the semantics reads off information about the event in its entirety by looking at $\mathrm{H}$-AspP, and it reads off information about the event internal properties by looking at L-AspP. From this we need not conclude that there is no $\mathrm{H}-\mathrm{AspP}$ in Russian, just that no phase verb heads H-AspP. Why this might be, I have nothing insightful to say about at this point.

However, note that if, as we suggested above, L-AspP is tied to the event internal properties of a predicate, we might expect that in Russian the presence vs. absence of L-AspP is tied to an eventive vs. a stative interpretation of the predicate, just as in English. If this were the case, we would expect the same patterns with Russian stative phase verb complements as we have seen with English gerundive stative phase verb complements. That is, some statives should be fine as phase verb complements, while others should not be. This appears to be just what we find, as observed in MacDonald (2009): 
(24) (a) *Vanja načal vesit' 100 kilogramm. Vanja began weigh impf $_{100 \text { kilograms }}$ 'Vanja began weighing 100 kilos.'

(b) *Vanja načal otsutstvovat' sredi zritelej. Vanja began be-absent impf $_{\text {among viewers }}$ 'Vanja began being absent from the audience.'

(c) *Maria perestala znat' fermera. Mary stopped knowimpf farmer-acc 'Mary stopped knowing a farmer.'

(25) (a) Maria perestala nenavidet' pivo. Mary stopped hate impf beer 'Mary stopped hating beer.'

(b) Maria načala ponimat' Vanju/otvet. Mary began understand $d_{\text {impf }}$ Vanja/answer 'Mary began understanding Vanja/the answer.'

(c) Maria perestala ljubit' Vanju. Mary stopped love impf Vanja-acc 'Mary stopped loving Vanja.'

The stative phase verb complements in (24) are ungrammatical, and those in (25) are grammatical. If Russian phase verbs head L-AspP, we could explain these patterns in the same way that we explained the patterns from English: the statives in (24) cannot shift to an eventive interpretation, while those in (25) can (whatever regulates stative-eventive aspectual shifts). We could appeal to the same explanation offered for English: stative phase verb complements in Russian are fine, but only on an eventive interpretation.

These data also raise a more general question about Russian phase verb complementation patterns. More concretely, the inability to appear as a phase verb complement has been taken as a reliable diagnostic of the perfective status of a verb. However, since the verbs in (24)-(25) are all imperfective - minimally none of them is derived via the addition of a perfectivizing prefix - and all are not able to appear as phase verb complements, something more has to be added. I suggest here that semantic properties of phase verb complements play a role in at least some of the phase verb complementation patterns. If the patterns in (24)-(25) are the result of stative eventive aspectual shifts, then it would follow that 
the aspectual class of the phase verb complement plays some role in its (in)compatibility.

\section{Conclusion}

By contrasting the syntactic properties of English and Russian phase verbs, we have seen that English phase verbs appear to head one of two aspectual functional projections: H-AspP, immediately above $v \mathrm{P}$ or L-AspP, between $v \mathrm{P}$ and VP, following work by Fukuda (2008; 2009). H-AspP is an aspectual functional projection that is related to viewpoint aspect ( $\grave{a}$ la Smith 1991), while L-AspP is an aspectual functional projection that is related to situation aspect (à la Smith 1991). More concretely, semantics reads off information about viewpoint aspect (i.e., the event in its entirety) by looking at $\mathrm{H}$-AspP, and it reads off information about situation aspect (i.e., the event internal properties) by looking at L-AspP. We also saw that Russian phase verbs appear to only head L-AspP. One potential implication of this was mentioned: some phase verb complementation patterns can be explained by appeal to the aspectual class of the phase verb complement.

\section{References}

Beck, Sigrid - William Snyder 2001. Complex predicates and goal PP's: Evidence for a semantic parameter. In: Proceedings of the 25th Boston University Conference on Language Development, 114-22. Cascadilla Press, Somerville MA.

Borik, Olga 2002. Aspect and reference time (LOT Dissertation Series 64). Landelijke Onderzoekschool Taalwetenschap, Utrecht.

Dickey, Stephen M. 2000. Parameters of Slavic aspect: A cognitive approach. CSLI, Stanford CA.

Dowty, David R. 1979. Word meaning and Montague grammar: The semantics of verbs and times in generative syntax and in Montague's PTQ. Reidel, Dordrecht.

Freed, Alice 1979. The semantics of English aspectual complementation. Reidel, Dordrecht.

Fukuda, Shin 2008. Two syntactic positions for English aspectual verbs. In: Proceedings of the 26th West Coast Conference on Formal Linguistics, 172-80. Cascadilla Press, Sommerville MA.

Fukuda, Shin 2009. Syntactic consequences of events in Japanese. Doctoral dissertation, University of California, San Diego.

Fukuda, Shin to appear. Aspectual verbs as functional heads: Evidence from Japanese aspectual verbs. Natural Language and Linguistic Theory. Cited version from http://idiom.ucsd.edu/ fukuda/ on 5.9.2011. 
Katz, Graham 2008. Manner modification of state verbs. In: Adjectives and adverbs: Syntax, semantics, and discourse, 220-48. Oxford University Press, Oxford.

MacDonald, Jonathan E. 2008a. Domain of aspectual interpretation. In: Linguistic Inquiry $39: 128-47$.

MacDonald, Jonathan E. 2008b. The syntactic nature of inner aspect: A minimalist perspective. John Benjamins, Amsterdam \& Philadelphia.

MacDonald, Jonathan E. 2009. Variation, aspectual interpretation and phase verbs. In: John Bailyn - Carlos de Cuba - Ivana Mitrović - Radmila Šević - Ljiljana Subotić (eds): Novi Sad generative syntax workshop 2 proceedings, 7-25. University of Novi Sad, Filozofski fakultet, Novi Sad.

MacDonald, Jonathan E. 2010. Minimalist variability in the verb phrase. In: Maia Duguine-Susana Huidobro-Nerea Madariaga (eds): Argument structure and syntactic relations from a cross-linguistic perspective, 69-88. John Benjamins, Amsterdam \& Philadelphia.

Marušič, Franc-Rok Žaucer 2006. On the intensional FEEL-LIKE construction in Slovenian: A case of a phonologically null verb. In: Natural Language and Linguistic Theory $24: 1093-159$.

Mufwene, Salikoko S. 1984. Stativity and the progressive. Indiana University Linguistics Club, Bloomington, Indiana.

Perlmutter, David 1970. The two verbs begin. In: Roderick A. Jacobs-Peter S. Rosenbaum (eds): Readings in English transformational grammar, 107-19. Blaisdell, Waltham MA.

Ross, John R. 1972. More on begin. In: Foundations of Language 8:574-7.

Rothstein, Susan 2004. Structuring events. Blackwell, Malden MA \& Oxford.

Schoorlemmer, Maaike 1994. Aspect and verbal complementation in Russian. In: Sergey Avrutin-Steven Franks - Ljiljana Progovac (eds): Proceedings of the MIT workshop on formal approaches to Slavic linguistics, 400-22. Michigan Slavic Publications, Ann Arbor.

Schoorlemmer, Maria 1995. Participial passives and aspect in Russian. Doctoral dissertation, Utrecht University.

Smith, Carlota 1983. A theory of aspectual choice. In: Language 59:497-501.

Smith, Carlota 1991. The parameter of aspect. Kluwer, Dordrecht.

Swart, Henriëtte de 1998. Licensing of negative polarity items under inverse scope. In: Lingua 105 : 175-200.

Travis, Lisa deMena 1991. Derived objects, inner aspect, and the structure of VP. Paper presented at the 22nd Annual Meeting of the North East Linguistics Society (NELS 22), University of Delaware.

Verkuyl, Henk J. 1972. On the compositional nature of the aspects. Reidel, Dordrecht.

Zucchi, Sandro 1998. Aspectual shift. In: Susan Rothstein (ed.): Events and grammar, 349-70. Kluwer, Dordrecht. 